\title{
The Role of Parental Attachment in Life Satisfaction with Gratitude as a Mediator for Adolescents in the Digital Era
}

\author{
Natashya Natashya ${ }^{1 *}$ Debora Basaria ${ }^{1}$ \\ ${ }^{1}$ Faculty of Psychology, University Tarumanagara, West Jakarta, Indonesia \\ "Corresponding author.Email: natashya.705170012@stu.untar.ac.id
}

\begin{abstract}
This digital era has quite a variety of impacts on adolescents. Some teenagers have life satisfaction and not in their lives. Thus, it affects attachment to their parents and has an impact on gratitude. This study aims to see how the role of parental attachment on life satisfaction with gratitude as a mediator for adolescents in the digital era. This study employed the Non-Experimental Quantitative method namely quasi-exprimental. The sampling technique used was purposive sampling. Participants in this study were adolescents in the age range 15-18 years old, 262 participants in total. There were three questionnaires used in this study, the Inventory Parent and Peer Attachment (IPPA) measurement tool by Armsden and Greenberg (1987), The Gratitude Questionnaire-6 (GQ-6) by McCullough et al. (2002), and Student's Life Satisfaction Scale by Huebner (1991). Data collection was carried out in mid-November. Data obtained were processed using regression tests with mediating variables. The results showed that there is a significant positive role of parental attachment on life satisfaction with gratitude as a mediator for adolescents in the digital era. Based on the results of the mediation test, it can be concluded that gratitude has a partial mediation role in the role of parental attachment on life satisfaction in adolescents in the digital era.
\end{abstract}

\section{Keywords: Parental Attachment, Life Satisfaction, Gratitude, Adolescents in the Digital Era}

\section{INTRODUCTION}

Adolescents are individuals who are in the age range of 10-12 years old and at the age of 18-21 years old at last (King, 2017) [1]. Adolescence has several characteristics, including adolescents starting to leave attitudes and behavior patterns in childhood and learning new attitudes and behavior patterns in preparation for entering adulthood. In adolescence, some things make teens feel comfortable and uncomfortable in their life. The researchers conducted personal communication with five teenagers who live in the digital era to support this study. The results showed that three adolescents were satisfied and attached to their parents. This was because these teenagers received support from their parents and friends on the things that they are doing. Their gratitude is also formed due to the attention and presence of parents who are able and willing to listen to all the stories. Moreover, two out of five teenagers felt less satisfied with their teenage life. This was due to the lack of intimacy and attention from parents. Besides, the circle of friends was not good for one of the two teenagers while another teenager felt he can tell everything with his parents but is not satisfied with his circle of friends which has a less good influence. Fortunately, he was still grateful for it (Personal communication, 2020).
Life satisfaction is psychological well-being or satisfaction with life as a whole (Santrock, 2012) [2]. Positive things in adolescent life leads to life satisfaction and vice versa. Thus, negative things that are felt by adolescents throughout adolescence cause life dissatisfaction. According to Ma and Huebner (2008) [3], things that affect life satisfaction are demographics, environment, and interpersonal relationships. One of the interpersonal relationships here is attachment. According to Bowlby (1982) [4], attachment is the behavior of fostering close relationships with individuals. According to Mikulincer et al. (2003) [5], secure attachment is a sense of comfort in the presence of closeness and interdependence, as well as the support search. Firestone (2019) [6] suggests that avoidant attachment is the behavior of individuals who avoid in the process of adapting to circumstances. There is also an anxiety attachment, a lack of security and the child feels rejected (Mikulincer et al., 2003). Previous research conducted by Koohsar and Bonab (2011) [7] proves that secure attachment has high results on life satisfaction. According to a study by Sharon and Wendy (Koohsar \& Bonab, 2011), anxiety and avoidant attachment have low results on life satisfaction levels. 
It turns out that in addition to research on attachment with life satisfaction, there are also studies involving the role of gratitude and life satisfaction. According to a study conducted by Yildirim and Alanazi (2018) [8], there is a positive relationship between gratitude in increasing life satisfaction. Besides, there are some studies involving attachment with gratitude. A study conducted by Lin (2019) [9] also shows that there is a positive relationship between parental attachment and the strength of gratitude. Thus, interaction with parents is important in shaping individual gratitude. One of the important characteristics associated with secure attachment and wellbeing is gratitude (Demirtaş, 2019) [10]. Gratitude interventions can improve individual welfare (Lin, 2019). In a study conducted by Lin (2019), secure attachment has a significant relationship with gratitude. Insecure attachment has a relationship with more ambivalent experiences of gratitude interactions because insecure individuals often feel that they are not worthy of the kindness of others.

Teenagers in the current era are identical with the use of gadgets. Thus, they are often referred to as the digital or millennial generation. Azzahra (2019) [11] stated that teenagers living in the millennial era may be familiar with social media. Many of them spend more time playing social media on their cellphones. The existence of social media causes children to rarely communicate with their parents. It makes parents worry about how satisfying life is in adolescents. Even so, the more often a teenager plays social media, the more time is wasted playing with his/her friends. Besides, sleep, exercise, and family time are lost when teenagers play social media. This is what makes the child's attachment to their parents disappear

According to Jannah (2020) [12], the negative impact of the excessive digital era on adolescents results in (a) insecurity in watching beautiful photo uploaded by other people related to their personal lives on social media that reveal self-doubt and perceive other individuals better than oneself, (b) anxiety, which can be seen from feeling anxious, worried, having trouble sleeping, and not concentrating for it is imagined by uploading photos that one's saw, and (c) jealousy, which is caused by feeling inferior due to watching the happiness of other individuals and certainly not good for adolescent development. These mak adolescents have low gratitude. According to Rossa (2019) [13], there is a positive impact of the digital era for adolescents, namely adolescents begin to show self-identity, to express themselves, to form communities, to do activities that are preferred, to obtain emotional support that leads to life satisfaction. Based on this phenomenon in the digital era, many teenagers have had a bad impact on their lives. However, some teenagers can control themselves. Researchers are also interested in researching the role of parental attachment to life satisfaction with gratitude as a mediator for adolescents in the digital era.

\subsection{Writing Structure}

Systematically, this study was written into five chapters. The first part contains a description of the discussion on the background of the problem, problem formulation, research objectives, the benefits of the study both theoretically and practically, and systematics of writing. The second part contains a description of the theory which forms the basis of the theory in this study and the framework. Meanwhile, the theory used was the theory of attachment theory, the theory of life satisfaction, and the theory of gratitude. The third section contains a part of the research methodology which contains criteria and descriptions of participants, types of research, research settings and tools, research measurement tools, research preparation, and implementation, as well as data processing and analysis techniques. The fourth section contains an overview of the research variables, the main data analysis which includes hypothesis testing, and additional data analysis. The fifth part is the closing which contains conclusions, discussions, and theoretical and practical suggestions.

\section{LITERATURE REVIEW}

\subsection{Attachment}

Attachment is determined by a close affectionate bond that includes a person's general feeling of security, trust, positive communication, and being supported and accepted in close relationships with others (Armsden \& Greenberg, in Keizer et al., 2019) [14]. Armsden and Greenberg (in Sari et al., 2018) [15] explained that there are three dimensions of attachment including the following; (a) Trust, parents give trust, understand needs, and respect choices and decisions, involved in resolving conflicts and problems that occur to adolescents. Parents still control the things that teenagers do both at school and at excess teenagers; (b) Communication, parents' guide adolescents to be open, discussing the problems faced both about themselves and problems with others. Parents can respond well to the emotional state being experienced by adolescents, the presence of concern, the ability to provide support and help solve problems faced by adolescents. Good contact between adolescents and parents will make a person accessible to any challenge they face; and (c) Alienation, alienation occurs when parents are less responsive to adolescents and do not give confidence in what adolescents do.

\subsection{Gratitude}

McCullough et al. (2002) [16] define gratitude as a general habit of acknowledging and responding with gratitude to the role of others in positive experiences and impacts on a person. Gratitude is unidimensional. 
The term gratitude is found in the Latin Gratia which is enjoyable and gratus which means fun. Gratitude is one of the most neglected emotions and one of the most underrated virtues (Emmons \& McCullough, 2004) [17].

\subsection{Life Satisfaction}

Life satisfaction is defined globally as an assessment of life as a whole and specific parts of an individual's life, such as satisfaction within the sphere of relatives, friends, and so on (Huebner, 1991) [18]. According to Ma and Huebner (2008), three factors influence life satisfaction, namely demographics, environment, and interpersonal relationships. Life satisfaction is unidimensional.

\section{METHODS}

\subsection{Participants and Research Design}

The criteria for participants in this study were adolescents in the range of 15-18 years old, male and female, have biological parents who are still alive and not divorced, live with biological parents (both are still alive), students at the high school level. This study did not limit race, ethnicity, religion, and also the socioeconomic status of research participants. The sampling technique used was purposive sampling. The total number of study participants was 262 participants.

\subsection{Research Instruments}

\subsubsection{Parental Attachment}

This study used the Inventory Parent and Peer Attachment (IPPA) developed by Armsden and Greenberg (1987) [19]. This scale measured three dimensions of parental attachment. 25 items were consisting of 21 positive items and 4 negative items. The type of scale used was the Likert scale with 5 (five) answer choices: (1) Strongly Disagree, (2) Disagree, Sometimes, (4) Agree, and (5) Strongly Disagree. Reliability test results can be seen in Table $1 \&$ Table 2.

Table 1 Parental Attachment Reliability Test on Mother Figure
Dimension
a Cronbach

\begin{tabular}{lcc}
\cline { 2 - 3 } & $\begin{array}{c}\text { Before } \\
\text { reliability test }\end{array}$ & $\begin{array}{c}\text { After } \\
\text { reliability test }\end{array}$ \\
\hline Trust & .868 & .868 \\
Communication & .830 & .855 \\
Alienation & .709 & .709 \\
\hline
\end{tabular}

Table 2 Parental Attachment Reliability Test on Father Figure

$$
\text { Dimension } \quad \alpha \text { Cronbach }
$$

\begin{tabular}{lcc}
\cline { 2 - 3 } & $\begin{array}{c}\text { Before } \\
\text { reliability test }\end{array}$ & $\begin{array}{c}\text { After } \\
\text { reliability test }\end{array}$ \\
\hline Trust & .885 & .885 \\
Communication & .844 & .874 \\
Alienation & .770 & .770 \\
\hline
\end{tabular}

\subsubsection{Gratitude}

This study employed the Gratitude Questionnaire-6 (GQ- 6_ developed by McCullough et al. (2002) which is unidimensional. 6 items are consisting of 4 positive items and 2 negative items. The type of scale used was a Likert scale with 7 (seven) answer choices: (1) Strongly Disagree, (2) Disagree, (3) Somewhat Disagree, (4) Neutral, (5) Somewhat Agree, (6) Agree, and (7) Strongly Agree. Reliability test results can be seen in Table 3 .

Table 3 Gratitude Reliability Test Dimension $\quad \alpha$ Cronbach

\begin{tabular}{ccc} 
& $\begin{array}{c}\text { Before } \\
\text { reliability test }\end{array}$ & $\begin{array}{c}\text { After reliability } \\
\text { test }\end{array}$ \\
\hline Gratitude & .392 & .674 \\
\hline
\end{tabular}

\subsubsection{Life Satisfaction}

This study used the Students' Life Satisfaction Scale developed by Huebner (1991) which is unidimensional. 7 items were consisting of 5 positive items and 2 negative items. The scale used was the Likert scale with 4 (four) answer choices: (1) Completely Not Suitable, (2) Somewhat Appropriate, (3) Somewhat Suitable, (4) Completely Suitable. The results of the reliability test of gratitude are presented in Table 4.

Table 4 Life Satisfaction Reliability Test

\begin{tabular}{ccc} 
Dimension & \multicolumn{2}{c}{$\boldsymbol{\alpha}$ Cronbach } \\
\cline { 2 - 3 } & $\begin{array}{c}\text { Before } \\
\text { reliability test }\end{array}$ & $\begin{array}{c}\text { After } \\
\text { reliability test }\end{array}$ \\
\hline Life Satisfaction & .714 & .714 \\
\hline
\end{tabular}




\section{FINDINGS AND DISCUSSIONS}

\subsection{Normality Test}

The normality test was carried out to prove the residual value, distributed or not. Researchers measured the residual normality using graphical analysis methods, by looking at tables and graphs that compare the observed data with a distribution close to normal. The results obtained show that the data distribution was around the diagonal line and followed the direction of the diagonal line. Thus, it can be concluded that the histogram graph shows a normal distribution pattern and meet the normality assumption of $p 200 \geq 0.05$. The results of the normality test can be seen in Table 5 below.
Table 5 Data Normality Test

Normality

p

Kolmogorov-Smirnov

\subsection{Hypothesis Testing}

Linear regression test on parental attachment to mother figures on life satisfaction with gratitude as a mediator in adolescents in the digital era. With the existence of mediating variable of gratitude, the significant value was $0.000<0.05$ tc $=4.458$. However, the value of parental attachment to mother figure on life satisfaction decreased with tc $=2.966 \mathrm{sig} 0.003<0.05$. The results of the regression test on parental attachment to mother figure on life satisfaction with gratitude as a mediator for adolescents in the digital era can be seen in the following Table 6 .

Table 6 Parental (Mother) Attachment Regression Test on Life Satisfaction with Gratitude as a Mediator for Adolescents in the Digital Age

\begin{tabular}{|c|c|c|c|c|}
\hline & $\begin{array}{c}\text { Unstandardized } \\
\text { B }\end{array}$ & $\begin{array}{l}\text { Coefficients } \\
\text { Std. Eror }\end{array}$ & $\mathbf{t}$ & Sig \\
\hline Constant & 0.664 & .339 & 1.957 & .051 \\
\hline Gratitude & 0.198 & .044 & 4.458 & .000 \\
\hline Attachment (Mother) & 0.235 & .079 & 2.966 & .003 \\
\hline
\end{tabular}

In the test of the role of parental attachment to the mother figure on life satisfaction, gratitude is a partial mediator for its role was directly smaller before the mediator variable $(\mathrm{t}=3.940)$ compared to when it passed through the gratitude mediator variable $(\mathrm{t}=4.458)$. All roles have a significant tc. This is reinforced by the calculation of the Sobel Test with a result of $2.952, p=0.0003<0.05$. This proves that gratitude is a mediator in testing the role of parental attachment to mother figures on life satisfaction. The Sobel test calculation is presented in Table 7.
Table 7 Calculation of the Sobel Test on the Role of Parental Attachment to Mother Figure on Life Satisfaction with Gratitude a Mediator for Adolescents in the Digital Age

\begin{tabular}{cccc}
\hline Sobel Test & & Sobel Test & Sig \\
\hline$t a$ & 3.940 & & \\
$t b$ & 4.458 & 2.952 & 0.003 \\
\hline
\end{tabular}

Linear regression test of parental attachment to father figure on life satisfaction with gratitude as a mediator in adolescents in the digital era showed that after the mediating variable of gratitude included, the value was sig $0.000<0.05$ with $t 4.656$. However, the value of parental attachment to father figures in life satisfaction decreased with $t_{c}=3.081$ sig $0.002<0.05$. The results of the regression test on parental attachment to father figure on life satisfaction with gratitude as a mediator for adolescents in the digital era can be seen in Table 8 . 
Table 8 Parental (Father) Attachment Regression Test on Life Satisfaction with Gratitude as a Mediator for Adolescents in the Digital Age

\begin{tabular}{lllrr} 
& \multicolumn{2}{c}{$\begin{array}{c}\text { with Gratitude as a Mediator for Adolescents in the Digital Age } \\
\text { B }\end{array}$} & $\begin{array}{c}\text { Coefficients } \\
\text { Std. Eror }\end{array}$ & Sig \\
& & & & \\
& & & 1.970 & 0.50 \\
Constant & 0.661 & 0.366 & 4.656 & .000 \\
Gratitude & 0.204 & 0.044 & 3.081 & .002
\end{tabular}

In the test of the role of parental attachment to the father figure on life satisfaction, gratitude is a partial mediator for its role was directly smaller before the mediator variable $(\mathrm{t}=3.045)$ compared to when it passed through the gratitude mediator variable $(t=4.656)$. SelALl roles have a significant tc. This is reinforced by the calculation of the Sobel Test with the results of $2.548, p=0.011<0.05$. It proves that gratitude is a mediator in testing the role of parental attachment to father figures on life satisfaction. The Sobel Test calculation can be seen in Table 9.

Table 9 Calculation of Sobel Test the Role of Parental Attachment to Father Figures on Life Satisfaction with Gratitude as a Mediator for Adolescents in the Digital Age

\begin{tabular}{|c|c|c|c|}
\hline Sobel Test & & Sobel Test & Sig \\
\hline$t a$ & 3.045 & & \\
\hline$t b$ & 4.656 & 2.548 & 0.011 \\
\hline
\end{tabular}

\subsection{Additional Analysis Test}

\subsubsection{Differences in Life Satisfaction on Gender}

This difference test was performed using the Independent Sample T-test. The research data show that the mean score of life satisfaction in male participants was $18.681(\mathrm{SD}=3.08456)$ and the mean score for female participants was $19.083(\mathrm{SD}=3.54045)$. Based on the test results, it is known that $\mathrm{F}=1.270, \mathrm{p}=0.261$ > 0.05 . It means that the two variances are the same $r$ homogeneous. Because of the significant similarity of the two variances, the use of variance to compare the mean gender (test for equality of means) used a t-test based on the equal variances assumed, $\mathrm{t}=-0.836, \mathrm{p}=$ $0.404>0.05$. Female adolescents $(\mathrm{M}=19.029$; $\mathrm{SD}=$ 3.540) had a higher life satisfaction than male $(\mathrm{M}=$ $18.681 ; \mathrm{SD}=3.085)$. These results indicate that there is no significant difference in life satisfaction between the gender of male and female. The test for differences in life satisfaction with gender is presented in Table 10.

Table 10 Test of Difference of Life Satisfaction Among Gender

\begin{tabular}{ccccccc} 
Gender & \multicolumn{7}{c}{$\begin{array}{c}\text { (To see } \text { equal } \\
\text { variances } \\
\text { assumed/not } \\
\text { assumed) }\end{array}$} & T & $P$ \\
\hline Gender & M & SD & & & & \\
\hline Male & 18.681 & 3.085 & 1.270 & .261 & - & .404 \\
Female & 19.083 & 3.540 & 1.270 & .261 & - & .404 \\
& & & & & .836 & \\
\hline
\end{tabular}

\subsubsection{Relationship between Gratitude and Life Satisfaction}

Since the data were normally distributed, the Pearson correlation was used. Through the results of the Pearson correlation test, the variables of gratitude and life satisfaction showed a positive and significant relationship, $\mathrm{r}(262)=0.309 ; \mathrm{p}<0.01$. In other words, the stronger the gratitude, the stronger the life satisfaction of the participants. In contrast, the weaker the participants' gratitude, the weaker their life satisfaction. The results of the test on the relationship between gratitude and life satisfaction.

Table 11 The Test of the Relationship between Gratitude and Life Satisfaction

\begin{tabular}{ccccc}
\hline & Mean & N & R & P \\
\hline Gratitude & 25.6527 & 262 & 0.309 & .000 \\
$\begin{array}{c}\text { Life } \\
\text { Satisfaction }\end{array}$ & 18.9771 & & & \\
\end{tabular}

The results of the main data test show that gratitude is a partial mediation in the role of parental attachment on 
adolescent life satisfaction in the digital era. In other words, there is a role for parental attachment on adolescent life satisfaction in the digital era, even though there is no mediating variable of gratitude. Yet, when the gratitude variable enters, parental attachment (independent variable) and life satisfaction (dependent variable) have decreased but still plays a significant role. The gratitude variable strengthens the role of parental attachment (independent variable) and life satisfaction (dependent variable). It can be seen when tested between parental attachment to a mother figure and life satisfaction before the mediating variable gratitude has a significant positive role. After the mediation variable, gratitude was included, it still has a significant positive role. However, after the mediating variable, the value of parental attachment decreased, but still has a significant role in the mediating variable, gratitude.

It can be seen when tested between parental attachment to a father figure and life satisfaction before the mediating variable gratitude has a significant positive role. After the mediation variable gratitude, it still has a significant positive role, but the value of parental attachment decreased. This study was conducted on adolescent participants in the digital era aged 15-18 years old.

The results of this study are in line with research conducted by Lin (2019), which states that gratitude mediates a positive relationship between parental attachment (father and mother) on life satisfaction. Gratitude is in the form of partial mediation. This study was conducted on young adult participants aged freshmen to seniors (late adolescents). Parental attachment not only has a direct impact on life satisfaction but also an indirect effect on life satisfaction through gratitude. Attachment is determined by a close bond of affection which includes a person's general feeling of security, trust, positive communication, and being supported as well as accepted in close relationships with others (Armsden \& Greenberg, in Keizer et al., 2019).

Moreover, additional research findings in this study found that there was no significant difference in life satisfaction based on gender. The results of this study are in line with research conducted by Chui and Wong (2016) [20], which states that there is no difference in life satisfaction based on gender. There is also a study conducted by Dew and Huebner (1994) [21], which states that there is no difference in life satisfaction based on gender.

However, this study is not in line with Al-Attiyah and Nasser (2013) [22], who stated that the life satisfaction of female adolescents is higher than that of boys in Qatar. This is because, in Qatar, there is gender segregation. The female community in Qatar cannot fully participate in the environment, but women in that society are empowered by a collective role that is determined by gender. Men in Qatar prioritize the interests of women, which leads to high life satisfaction for women in Qatar. That study was inconsistent with other studies. Raboteg-Šarić et al. (2009)

[23] suggested that the life satisfaction of boys is higher than that of girls. There are also results of research conducted by Levin et al. (2012) [24], which stated that life satisfaction of boys is higher than girls.

Besides, there are additional research results. In this study, there is a positive and significant relationship between gratitude and life satisfaction. This study is in line with the research of Datu and Mateo (2015) [25], which states that there is a significant positive relationship between gratitude and life satisfaction. Fagley (2012) [26] states that there is a significant positive relationship between gratitude and life satisfaction, which means that the tendency to be grateful leads to high life satisfaction. However, it was found that the findings of this study were not in line with another study which said that there was a significant negative relationship between gratitude and life satisfaction (Salvador-Ferrer, 2017) [27]. Researchers suggest for the future researchers to carry out further research to link other mediating variables for which information they want to know besides gratitude, such as seeing the effect of gratitude with self-esteem as mediation of life satisfaction or linking with other mediating variables such as self-efficacy, emotional intelligence, and subjective well-being.

\section{CONCLUSIONS}

Based on the results of the study, it can be concluded that there is a significant positive role of parental attachment on life satisfaction with gratitude as a mediator for adolescents in the digital era. Based on the results of the mediation test, it can be concluded that gratitude has a partial mediation role in the role of parental attachment to life satisfaction in adolescents in the digital era. This can be seen from the change in the significant value of parental attachment on life satisfaction before and after the gratitude variable.

\section{ACKNOWLEDGMENT}

Reseacher would like to thank to Tarumanagara University for the opportunity, every participant who was participate and contribute in this research.

\section{REFERENCES}

[1] King, L (2017). Experience Psychology (4 ed.). McGraw-Hill Higher Education.

[2] Santrock, J. W. (2012). A tropical approach to lifespan development (6th ed.). McGraw Hill

[3] Ma, C.Q., \& E. Scott Huebner. (2008). Attachment relationships and adolescent's life satisfaction: Some relationships matter more to girls than boys. Psychology in the Schools, 45(2), 177-190. 
https://doi.org/10.1002/pits20288

[4] Bowlby, J. (1982). Attachment and loss vol. 1. Tavistock Institute of Human Relations.

[5] Mikulincer, M., Shaver, P. R., \& Pereg, D. (2003). Attachment theory and affect regulation: The dynamics, development, and cognitive consequences of attachment-related strategies. Motivation and Emotion, 27(2), 77-102. https://link.springer.com/ content/pdf/10.1023\%2FA\%3 A1024515519160.pdf

[6] Firestone. (2019, April 2). Do you or your partner have an avoidant attachment pattern? Psychology today. https://www.psychologytoday.com/us/blog/ compassion-matters/201904/do-you-or-your-partner-have avoidant-attachment-pattern

[7] Koohsar, A. A. H., \& Bonab, B. G. (2011). Relation between quality of attachment and life satisfaction in high school administrators. Procedia Social and Behavioral Sciences, 30, 954-958. https:// doi.org/10.1016/j.sbspro.2011.10.185

[8] Yildirim, M., \& Alanazi, Z. (2018). Gratitude and life satisfaction: Mediating role of perceived stress. International Journal of Psychological Studies, 10(3), 21. https://doi.org/10.5539/ijps.v10n3p21

[9] Lin, C. C. (2019). Attachment and life satisfaction in young adults: The mediating effect of gratitude. Current Psychology. https://doi.org/10.1007/s12144019-00445-0

[10] Demirtaş, A. S. (2019). Secure attachment and mental well-being: Gratitude, hope and ego- resiliency as mediators secure attachment and mental well-being: Türk Psikolojik Danışma ve Rehberlik Dergisi, 9(54), 937-964. https://www.researchgate.net/publication/ 337534430_Secure_Attachment_and_Mental_Well_Be ing_Gratitude_Hope_and_Ego-Resiliency_as_ Mediators

[11] Azzahra, Q. (2019, Mei 08). Kepuasan hidup remaja bukan dari media sosial. Gatra.com. https://www.gatra.com/detail/news/414671/milenial/ke puasan-hidup-remaja-bukan-dari-media-sosial

[12] Jannah, S. (2020, September 3). Pengaruh penggunaan media sosial pada remaja terhadap kesehatan mental. Suara.com. https://yoursay.suara.com/ news/2020/09/03/121130/pengaruh-penggunaan-mediasosial-pada- remaja-terhadap-kesehatan-mental

[13] Rossa, V. (2019, Juli 30). Orang tua harus tahu, ini dampak media sosial pada remaja. Suara.com. https://www.suara.com/health/2019/07/30/133850/oran gtua-harus-tahu-ini-dampak-media-sosial- pada-remaja

[14] Keizer, R., Helmerhorst, K. O. W., \& van Rijnvan Gelderen, L. (2019). Perceived quality of the mother- adolescent and father-adolescent attachment relationship and adolescents' self-esteem. Journal of Youth and Adolescence, 1203-1217. https://doi.org/ 10.1007/s10964-019-01007-0

[15] Sari, S. L., Devianti, R., \& Safitri, N. (2018). Kelekatan orang tua untuk pembentukan karakter anak. Educational Guidance and Counseling Development Journal, 1(1), 17-31. http://dx.doi.org/10.24014/egcdj. v1i1.4947

[16] McCullough, M. E., Emmons, R. A., \& Tsang, J. A. (2002). The grateful disposition: A conceptual and empirical topography. Journal of Personality and Social Psychology, 82(1), 112-127. https://doi.org/10. 1037/0022-3514.82.1.112

[17] Emmons. R. A., \& McCullough, M. E. (2004). The psychologyof gratitude. Oxford University Press.

[18] Huebner, E. S. (1991). Initial development of the Student's Life Satisfaction Scale. SAGESocial Science, 12, 231-240. https://doi.org/10.1177/ 0143034391123010

[19] Armsden, G. C., \& Greenberg, M. T. (1987). The inventory of parent and peer attachment: Individual differences and their relationship to psychological well-being in adolescence. Journal of Youth and Adolescence, 16(5), 427-454. https://doi.org/10.1007/ BF02202939

[20] Chui, W. H., \& Wong, M. Y. H. (2016). Gender Differences in Happiness and Life Satisfaction Among Adolescents in Hong Kong: Relationships and Self- Concept. Social Indicators Research, 125(3), 1035- 1051. https://doi.org/10. 1007/s11205-015-0867-z

[21] Dew, T., \& Huebner, E. S. (1994). Adolescents' perceived quality of life: An exploratory investigation. Journal of School Psychology, 32(2), 185-199. https://doi.org/10. 1016/0022-4405(94)90010-8

[22[ Al-Attiyah, A., \& Nasser, R. (2016). Gender and age differences in life satisfaction within a sexsegregated society: Sampling youth in Qatar. International Journal of Adolescence and Youth, 21(1), 84-95. https://doi.org/10.1080/02673843. 2013.808158 
[23] Raboteg-Šarić, Z., Brajša-Ţganec, A., \& Šakić, M. (2009). Life satisfaction in adolescents: The effects of perceived family economic status, self-esteem and quality of family and peer relationships. Drustvena Istrazivanja, 18(3), 547564.

[24] Levin, K. A., Dallago, L., \& Currie, C. (2012). The association between adolescent life satisfaction, family structure, family affluence and gender differences in parent-child communication. Social Indicators Research, 106(2), 287-305. https://doi.org/10.1007/s11205-011-9804-y

[25] Datu, J. A. D., \& Mateo, N. J. (2015). Gratitude and life satisfaction among Filipino adolescents: The mediating role of meaning in life. International Journal for the Advancement of Counselling, 37(2), 198-206. https://doi.org/10. 1007/s10447-015-9238-3

[26] Fagley, N. S. (2012). Appreciation uniquely predicts life satisfaction above demographics, the big 5 personality factors, and gratitude. Personality and Individual Differences, 53(1), 59-63. doi: 10.1016/j.paid.2012.02.019

[27] Salvador-Ferrer, C. (2017). The relationship between Gratitude and Life satisfaction in a sample of Spanish university students. Anales de Psicología, 33(1),114-119. https://doi.org/10.6018/ analesps.32.3.226671 